\title{
Hijacking culture: The disconnection between place culture and place brands
}

\author{
This document is an early version of: \\ Kavaratzis, M. And Ashworth, G.J. (2015) Hijacking Culture: The disconnection between \\ place culture and place brands, Town Planning Review, 86 (2), 155-176.
}

\begin{abstract}
This article argues that the dominant understanding of culture within place branding is inadequate and leads to disconnection between local culture and the place brand. The article discusses significant tensions arising from an evident oversimplification of the relationship between place brands and culture. This relationship is reconstructed through a re-appreciation of its complexity and reciprocity. The article provides a refined appreciation of the role of place brands in the production of culture as well as of the cultural nature of place brands and explores the implications of such thinking. Synergies are found in clarifying the formation and function of place brands as cultural phenomena, and, particularly, in understanding the link that culture provides between locals, their place and its brand. The simultaneous consideration of culture in, for and of the place and the related analytical, strategic and participatory aspects of place branding are highlighted as resolutions to the evident tensions.
\end{abstract}

Keywords: Place Branding, Place Marketing, Culture, City Branding, Cultural Planning 


\section{Hijacking culture: The disconnection between place culture and place brands}

\section{Introduction to 'hijacking culture'}

In November 2011 the Greek Ministry of Culture and Tourism announced a marketing activity to promote Greece as a tourism destination in the USA (Poutetsi, 2011). Forty paintings donated by twenty contemporary Greek painters were printed on seven million placemats in 3,500 Greek restaurants in six states, in order to expose Americans to positive messages about Greece while they were eating. Reactions to the initiative have ranged from welcoming (at least, it cost nothing to Greek tax-payers) to condemning for being superficial and because "Greece deserves better than placemats" (Pappas, 2011). This campaign is an example of a well-established trend of using culture and the arts in branding places. The example highlights issues concerning the why, what and how of this trend. For instance, the placemats featured contemporary paintings not photographs of sunbathers or classical buildings. Might this be indicative of a desire to move away from the overused sea-sun-sand image towards culture and to move away from Classical Greek heritage and instead focus on modern Greece and its culture? What is it that makes contemporary paintings more appropriate for branding Greece than other possible elements (e.g. sculptures, music or dance) and how does one choose between these? Is the Greek theme of the paintings recognisable by all? Is it effective and appropriate for insiders and outsiders however legitimate such a distinction may be?

This article deals with such questions around the relationship between culture and place branding. It examines whether the understanding of culture exhibited in place branding is just a simplification of its much more complex roles. It assesses the goals of such place branding and the extent to which they accord with wider cultural development goals. Central to the article is a culturally informed understanding of place brands. The main argument is that while culture is central to place branding, the relationship is complex and needs to be treated with caution. Furthermore, 
place branding not only is informed and affected by culture but also informs and affects it; an aspect largely neglected in practice and the literature. The current use of culture in place branding does not reflect the complexity of this relationship. While branding claims to appreciate the role of culture and actually be based on culture, the two are rather disconnected and branding seems often to 'hijack' culture. This 'hijacking' refers to the interpretations of culture that are dominant within place branding, the explicit and implicit reasons this is attempted, the emphasis on certain cultural elements over others and the wider effectiveness of culture-based strategies.

It is important to highlight that the article does not argue against the use of culture within place branding. What it attempts is to suggest more refined understandings of such use and ways in which this can be attempted more effectively. To this end, the article proposes theoretically informed but practically relevant solutions to the problems caused by what we see as a disconnection between place branding and culture in current theory and practice. To put it simply, the charge examined here is that the use of culture in place branding is superficial and such place branding is ineffective because it ignores its own potential complexity and its own effects. Instead of this disconnection, culture and branding can work in synergy if their reciprocal relationship is understood. We argue for more refined interpretations of culture within place branding and for closer considerations of the cultural nature of place brands, both of which will work towards more synergy and fewer cases of 'hijacking culture'.

\section{Different approaches to place brands}

Place branding is an approach to urban governance that includes a set of activities and methods with the general aim to forge and project a desirable place image (Kavaratzis and Ashworth, 2005). The expected benefit is the strategic role that can be played by the place brand in attracting visitors, investment and in increasing local pride by identifying the particular place and differentiating it from similar places. This is done through a network of associations (Zenker and Beckmann, 2013a) with 
the place that is formed in peoples' minds. In order to influence this network of associations, a place branding process can be followed, which has been described in several different ways (e.g. Hankinson, 2004; Govers and Go, 2009; Kavaratzis, 2009; Hanna and Rowley, 2011). For our needs here, these can be effectively summarised as the Analytical Phase (research and analysis of the city, its resources, its image and perceptions), the Strategic Phase (development of strategic actions and tactical measures to create or influence the place brand) and the Participatory Phase (although not included in all suggested frameworks, this is a phase of consultation and dialogue with the several groups of stakeholders).

In terms of the published academic commentaries, we can distinguish four types of studies (for a comprehensive review see Lucarelli and Berg, 2011). First, there are managerial studies that examine the development of place brands as a result of a managerial process (e.g. Kotler et al, 1999; Moilanen and Rainisto, 2010). Secondly, there are integrated studies that attempt to examine the place brand in connection to wider processes and integrate these in the branding process (e.g. Aitken and Campelo, 2011; Anholt, 2007; Braun, 2012; Govers and Go, 2009; Hankinson, 2004; Hanna and Rowley, 2011; Kavaratzis, 2004; Zenker and Beckman2013a). Thirdly, there are critical studies that approach place brands from a highly critical perspective revealing their implicit goals and agendas (e.g. Broudehoux, 2001; Colomb, 2011a; Evans, 2006; Greenberg, 2008; Julier, 2005). Finally, it is relevant for the argument made in this article to note a fourth stream of studies that expand the integrated and critical stands towards a culturally-informed approach to place branding (e.g. Jensen, 2007; Mayes, 2008; Pike, 2011; Colomb 2011a; Giovanardi, 2011; Kalandides, 2011; Scaramanga, 2012; Ashworth and Kavaratzis, 2014).

It is within this approach that this article attempts to contribute by conceptualising the relationship between culture and the place brand. Of course, culture is notoriously difficult to define. It can be understood as a 'shared system of meaning' (e.g. McEwan, 2005) that helps people make sense of the world and is shared through a variety of 'cultural' practices that are shaped by and simultaneously shape culture. Thus, culture is socially defined and constantly redefined (e.g. Rodseth, 
1998). Culture is a process, something that people are involved in (Crang, 1998) rather than an end result and it is open to varying interpretations. Meethan (2001: 115) insightfully notes that "the fact that it is open to many interpretations indicates that rather than attempting to uncover its essence, we should rather focus on the ways and contexts in which it is used". This is precisely what we are attempting here by examining how culture is used for place branding purposes and identifying interpretations of culture that become evident.

\section{How is culture used in place branding?}

The increased use of culture for urban development purposes has led to a "just add culture and stir" (Gibson and Stevenson, 2004) approach, which has been associated with the desire to redefine the images of cities (Bianchini, 1993) and to diversify the economic base by compensating for job losses in manufacturing (Kunzman, 2004). The logic is to present the place as attractive to both cultural tourists and the so-called 'creative class' (Florida, 2002). Culture is thought to be crucial to the 'narrative of the place' (see Jensen, 2007), which branding may tap into and reinforce. Ashworth and Kavaratzis (2014) provide a tentative list of reasons for which culture is used within place branding: culture provides consumable (and saleable) experiences; culture acts as a resource for economic activity; culture attracts the 'creative class'; culture attracts tourists and, finally, culture expresses the locality.

For these reasons, three techniques are invariably used in various combinations. These can be termed 'event hallmarking', 'personality association', and 'flagship building and signature district', (Ashworth, 2009).

Technique 1: 'Event Hallmarking' 
As Richards and Wilson (2004: 1931) testify, "cities have long used mega events such as World Fairs, Expos and sporting events as a means of revitalising their economies, creating infrastructure and improving their image". Such events - and smaller such as local festivals - are held to strengthen local appreciation of the place's cultural past or to showcase the place's potential for cultural creativity and contemporary cultural production. Larger occasions such as the title of European City of Culture, or what Gibson and Stevenson (2007) have termed the 'Glasgow model', are also called upon to create an international image of the place as a cultural centre. This technique has been extensively analysed in the literature (e.g. Richards and Wilson, 2004; Quinn, 2005; 2006) and is commonly associated with cities becoming objects of consumption (e.g. Harvey, 1989) following the increased significance of the symbolic (Zukin, 1995) and the experience (Pine and Gilmore, 1999) economies. "In such a climate, cultural events in particular have emerged as a means of improving the image of cities, adding life to city streets and giving citizens renewed pride in their home city" (Richards and Wilson, 2004: 1932).

The potential role of all types of events in branding the place as 'cultural' might be significant. However, such activities need clear strategic direction (Ashworth and Kavaratzis, 2014) and their effects need to be considered not only in economic terms (Garcia, 2005). As Quinn (2005: 927) asserts,

"the outcomes of cities' engagement with arts festivals, however, remain little understood, particularly in social and cultural terms city authorities tend to disregard the social value of festivals and to construe them simply as vehicles of economic generation or as 'quick fix' solutions to city image problems".

What is often encountered is the organization of a multitude of different events including small and large, traditional and progressive, events based on many art forms and so forth. The critical question is whether this type of 'all events go' strategy is effective in creating or reinforcing a cultural place brand and there is evidence that the links between festivals and the host city are very weak (Van Aalst and van Melik, 2011). A further question relates to the purpose of these events as a means of promoting local cultural development; of establishing local cultural features in order to 
preserve and strengthen a cultural past; or of attracting external audiences in order to foster tourism development. Can a single event or the array of events staged work towards achieving these goals? Boland (2010) shows how local culture is actually sanitized through events such as the 'European Capital of Culture'. Quinn's (2006) investigation of two Irish arts festivals shows the tensions evident in such strategies. Her findings suggest on the one hand that using the festivals to attract tourists has not only led to increased revenue but, perhaps more importantly, to increased arts activity all-year-round. On the other hand, "problems were identified with respect to the quality of the relationship forged between the festivals and local populations in the respective places" (Quinn, 2006: 288).

\section{Technique 2: 'Personality Association'}

The forging of an association between a place and a named individual in the expectation that the necessarily unique qualities of the individual are transferred to the place, which thus enhances its individuality, is very common (e.g. Ashworth, 2010; Giovanardi, 2011; Scaramanga, 2012). Indeed the early and evident successes of this technique (see Ashworth, 2010) have prompted an almost universal application of it in the, usually mistaken, belief that it is a sure and easy route to successful branding. The selection of an individual from the creative arts is the most common; for instance, Scaramanga (2012) refers to the link between Paul Cezanne and Aix-de-Provence. This is thought to have two advantages. First, the history of cultural production provides a rich quarry of possibilities and, secondly, such a choice proclaims not only that this place is different but also that it is culturally creative. The chosen personality is required to be recognisable or capable of being made recognisable. The person-place link is attempted particularly when it is more or less realistic with the possibility of association through the history of the person's career, links to the art works themselves or to associated sites (e.g. Barcelona with Gaudi, Vienna with Hundertwasser, Paris with Art Nouveau). An interesting example is given in Giovanardi's (2011) investigation of the Italian city 
of Urbino and its link to the painter Raphael. Giovanardi (2011) shows that, while it is most commonly tourism purposes that lead local authorities to initiate such personality-place associations, the residents of the place might embrace such initiatives in surprising ways. Some of the city's residents "went beyond by producing discourses in support of a more intensive exploitation of Urbino's cultural and heritage resources" (Giovanardi, 2011: 64).

A point to consider, of course, is that some personalities from the creative arts often prove more suitable than others (Ashworth, 2010). Furthermore, the popular appreciation of art is to a large extent fashion-driven and places may find themselves successfully associated with people, styles or periods whose appreciation has waned or changed. A link once seen as effective and beneficial may become less effective or less relevant as fashions change. Place-personality associations may long outlive their usefulness and yet prove difficult to alter or erase from consumer consciousness. Finally, and frequently overlooked, the associations transferred from person to place need to be appropriate to the brand being created. Perhaps what is at work here is the same dynamic that has been observed in the more general branding literature with its emphasis on celebrity endorsement (e.g. Erdogan, 1999; Keel and Nataraajan, 2012). The congruity of the personality's image and the endorsed brand is of crucial importance. When the celebrity and the brand are seen to fit, the endorsement has positive effects but when there is no perceived fit the endorsement results in negative evaluations (Keel and Nataraajan, 2012). A relevant place branding example comes from the Canadian city of Stratford, Ontario, named after Shakespeare's birthplace (Stratford upon Avon, UK). Despite no historic connection to the great playwright, the city has managed to 'forge' such associations. The Shakespearean Gardens opened in the city in 1936 and a Shakespeare Festival was established in 1953 by the Stratford Shakespearean Festival Theatre. The festival has proven to be very successful (it celebrated its $60^{\text {th }}$ edition in 2013) having now expanded its repertoire to classical theatre in general. However, the city is clearly less eager to embrace its relation to its very famous contemporary child, pop star Justin Bieber who was born in the city in 1994. History is no guarantee of longevity of reputation but it makes it more likely and thus past 
creative personalities are considered safer choices than contemporary celebrities, whose fame may be transient or equivocal.

\section{Technique 3: 'Flagship Building and Signature District'}

The physical appearance and visual qualities of the local environment is an instrument of place branding available to local governments. The main applications of this are flagship buildings and signature districts. Flagship building refers to officially designed structures intended not only to house distinctive public functions but equally to convey, through their very physical presence, statements about the governments that erected them. They are flagships of much more general policies and ideas than the utilitarian functions they perform. This is an idea of long antiquity as few rulers or dominant ideologies have resisted the temptation to express themselves to their citizens and to posterity. The choice is between the historical and the contemporary or even futuristic design. Both strive to be noticed but the first proclaims that the place is durable and traditional while the second that it is creative and experimental. For success, aesthetic quality is less important. The architecture must be notable so that sight of the structure evokes the place.

An extreme manifestation of the use of flagship structures is known as the Guggenheim effect after the well-known Guggenheim museum in Bilbao, Spain (designed by Frank Gehry). The objective of the city of Bilbao was to change a faltering manufacturing economy and industrial image to a service economy and cultural image through a single building, which both contains culture and is itself culture. The Guggenheim Bilbao has set the example for spectacular buildings that are built around the world in the hope that they "will have a strong positive impact on the place perception not only as an additional (tourist) attraction or for improving residential pride but foremost for changing the image of the place" (Zenker and Beckmann, 2013b: 643). The museum has certainly been successful in changing the image of Bilbao and Plaza (2000) argues that it has generated flows of tourists in a place where these did not exist. However, Gomez and Gonzalez (2001) note that what 
never happened was the economic revitalization of the city, regarded as an almost automatic outcome of such projects. So, the design might be arresting and the tourists might have followed but the museum has not brought the regeneration that was promised (see for a critique Evans, 2006). The extent to which it has provided any stimulus for local cultural creativity is also doubtful (Ashworth and Kavaratzis, 2014).

Another common strategy could be labelled global hyper-modernity. Here the stress is firmly upon 'the city of the future' and upon the place as global phenomenon. A particularly spectacular manifestation of this has been labelled ‘Dubaisation' (Al Raouf, 2006), where newly prosperous Gulf States seek to remedy their existing weakly differentiated brands by uncompromisingly spectacular statements, often architectural, of their international position. This is a clear rejection not only of a past regarded as outdated but also of locality.

An extension of flagship building is the wider signature district, in which distinctive and pervasive design elements are introduced into public space. Signature design may be conveyed through an ensemble of related buildings, spaces and streetscape elements, including signage, paving, street furniture and nomenclature that make statements about the place. The objective, as with flagship structures, is not just a coherent unity in itself but differentiation from other places and recognition internally and externally. Such signature design often extends to the creation of a specific cultural district within a city that reflects upon the city as a whole. These could be artists' colonies, creative clusters or 'Museum districts', which have become something of a cliché, even in, or perhaps especially in, cities whose main activities and image have little to do with culture (e.g. Museumufer in Frankfurt am Main). In all of these the place attempts to acquire an association with artistic and entertainment production and consumption, through the shaping of a single distinctive district within it (the 'Temple Bar effect', Gibson and Stevenson, 2007).

It is often not the historicist perspective of the museum-district that is emphasised but the idea of a living community of artists, which is associated with a contemporary creative potential. Ashworth and Kavaratzis (2014) term this 'the Montmartre effect' and describe the usual trajectory 
of the development of such creative colonies subsequent to their spontaneous creation. What follows is their discovery by the cultural cognoscenti, then by those who desire an association with such an artistic atmosphere. These are then followed by cultural tourists who are guided by reports in 'creative' magazines and specialised tourist guidebooks. This gives the wake-up call to city authorities to start devising plans and regulations to shape the 'creative district', invariably within the framework of the city brand. All this attention and planning has, of course, encouraged the 'creatives' to leave in search of the next colony and what is left is a lingering ambiance still saleable to tourists. It is this trajectory that has led Evans (2001:172) to pronounce that "artists are the storm-troopers of gentrification" and Zukin (2010) to allude to the 'Trojan Horse' concealing the entry of real estate brokers.

As Ashworth and Graham (2012) point out, it is important that the model is considered effective by local authorities and that the building or district acts as a symbol of both the newly refound sense of pride for the residents and an appealing image to visitors and investors. However, Grodach (2010) points out that success of such projects depends on several contextual factors and suggests that they should attempt to build on existing cultural activity. Zenker and Beckmann's (2013b) investigation of the effects of three flagship projects in Hamburg, Germany found that while there is a positive change in the perceptions of the city, there were negative side effects relating to these perceptions. These were a minimising effect on the perceived significance of other attractions in the city and the decreased association of the city with 'multiculturalism' and 'openness' (Zenker and Beckmann, 2013b). Criticism against such flagship projects is intense and concentrates on their possible negative social side-effects (e.g. Miles and Paddison, 2005; Gospodini, 2009) in terms of social divisiveness (e.g. Swyngedouw et al, 2002) and gentrification (e.g. Zukin, 2010). Such signature structures attempt to impose new points of view but "negotiating whose point of view and the costs of imposing it creates problems for public culture" (Zukin, 1995: 24). 


\section{Tensions created}

Figure 1 depicts the superficial relationship between culture and place branding as observed in the implementation of the above techniques.

\section{'INSERT FIGURE 1 AROUND HERE'}

The attempt is to display the city's cultural offering in an alluring manner, largely based on the interpretation of culture as the production of aesthetic experiences. As Scaramanga (2012) observes, in urban planning and place branding the obvious understanding of culture is centred on arts, history, events and cultural facilities. Thus branding attains presumably easily managed tangible evidence of brand associations, with straightforward links to tourism. This understanding of culture is superficial and, as we argue below, leads to a disconnection between place brands and local culture that creates a series of tensions encapsulated in what we term the 'hijacking' of culture. For instance, the focus is clearly on the economic returns of projects and strategies although sustainability must be considered also in social (Gospodini, 2009) and cultural terms (Garcia, 2005). All culture-related policies are judged by their contribution to the collective process of meaning-creation and to social cohesion (Miles and Paddison, 2005). Several tensions are discussed below within three separate themes: a) the drawbacks of currently dominant interpretations of culture, b) the benefits of cultural interpretations of place brands and c) the tensions generated by the search for the global.

\section{Branding interpretations of culture}

The first drawback is the evidence of a simplistic and deterministic view of the production of culture, which place branding is called to tap into. The effort of place branding is to offer culture ready for consumption; to produce cultural artefacts for people to buy into and consume. This is attempted by 
interventions in a single process presumably leading to the production of culture. As Rantisi and Leslie (2006) have argued regarding the branding of Montreal, Quebec as a design Metropolis, such initiatives aim at creating a spectacle to be consumed rather than a long-term process and focus on culture "as artefact rather than as process, ignoring the need for a multifaceted [cultural] strategy" (2006: 374).

However, culture and cultural artefacts are not created through simple production steps but through the "articulation of a number of distinct processes whose interaction can and does lead to variable and contingent outcomes" (Du Gay et al, 1997: 3). As the influential 'circuit of culture' (Du Gay et al, 1997) explains, in order to understand how cultural artefacts acquire their meaning, we need to study how they are represented, how they relate to social identities, how they are produced, how they are consumed and how their use is regulated. It is the interplay between all five of these elements that leads to an understanding of the meaning of culture. Instead, place branding currently attempts to use only the representation and to an extent the production elements of the circuit as is evident in our earlier account.

To complicate matters, not even this limited view of culture's production is treated with adequate attention. Evans (2001) proposes what he calls the 'cultural production chain', which analyses the interrelated links of a production chain of culture and the arts. The stages included are: the beginnings (the generation of ideas), production (transforming the ideas into marketable products), circulation (the assembling and dissemination of the products), delivery (facilities necessary for the products to be experienced and enjoyed) and audiences (the reception of the products by the market) (Evans, 2001). The important point is that there are distinct needs for different types of infrastructure and investment in education and training, in research and development, in technology and transport, in intermediaries and agents and more. Current place branding, however, pays little attention to such prerequisites of cultural production.

The second drawback of the mechanistic view of culture is the treatment of culture as a place asset, which is followed by the assumption that culture can be manufactured and managed 
through certain interventions. The idea is that the place's culture will be created and directed with specific 'cultural' interventions in physical or symbolic spaces. This is a view of culture as a place asset: something the place has. The logic is that if the place has little (or the wrong) culture we can install some more (or better) culture. This assumption is based on the view "of culture as a detectable and distinctive variable" (Brewis and Jack, 2011: 234) but it ignores the organic nature of culture. It ignores the fact that culture grows through collective, dynamic and on-going processes (Brewis and Jack, 2011). In this logic, culture is better understood as something the place is (see Ortner, 1973; Smircich, 1983) rather than something the place has. Furthermore, the uses of culture described above demonstrate the mistaken belief that culture can be imposed on people, whether insiders or outsiders, who can be persuaded that their own culture is about specified elements. Moor (2011: 76) effectively raises this point with her concern "about the extent to which the activities of powerful institutions are able to shape the uses to which material culture may be put by ordinary people". However, what is being ignored is the socially-constructed nature of culture and the participatory processes that are involved in its making (see Rodseth, 1998; Crang, 1998; MacEwan, 2005).

\section{Cultural interpretations of place brands}

Another significant factor that leads to the disconnection between culture and place branding is that currently, the other side of the reciprocal relationship between place brands and culture, namely the cultural nature of place brands, is ignored. Contemporary place branding seems to subscribe to a rather authoritative view of the pace brand as a suggestion that people are supposed to believe and adopt. This is something that has been criticised and warned against in the place branding literature that highlights the need for more responsible approaches and more respectful practices (e.g. Kavaratzis, 2004; Anholt, 2007; Kalandides, 2011; Zenker and Seigis, 2012). The desire in current place branding practice is for people to internalise the 'right' brand as this is offered ready-made by 
place brand managers. This assumption ignores the cultural processes through which people make sense of place brands. We argue that place brands would be better understood not as prescriptive but as permissive; not as dictating views but as offering suggestions (see also Aitken and Campelo, 2001; Kavaratzis and Hatch, 2013). Not least, because such suggestions will inevitably be met with as much resistance as acceptance, as much disagreement as agreement, as much dislike as sympathy and as much dissatisfaction as satisfaction. This is what Giovanardi (2011) refers to as 'the moment of readings' when the place brand is 'read' by audiences whose attempt to make meaning of it leads to different readings. These alternative readings of the place brand do not decrease the value of the branding exercise; they simply re-orientate it. For instance, current place brands aim at providing shorthand for places (or what anthropologists would call 'summarizing symbols' - see Ortner, 1973). Instead, it might be closer to the cultural nature of place brands to provoke discussions and thought; to cause elaboration over the place in peoples' minds ('elaborating symbols'). What a cultural view allows us to see is that instead of conclusive presentations of what the place is place brands might be better thought of as invitations to think about and discuss what the place is.

This need to address the ways in which place brands will be 'read' leads to another benefit of the cultural approach towards place brands. It allows us to look at them through the lenses of the 'Circuit of Culture' examined above. In order to understand the functions and effects of place brands as cultural phenomena, it is necessary to consider all stages of representation, production, consumption, relation to social identities and regulation (Du Gay et al, 1997). This means that there is a need to understand both their production and their consumption; both their acceptance and the resistance they invoke; both their regulation and their inherent need for flexibility; both the representation and the represented.

\section{The search for the global}


A cause of several tensions related to our analysis here is the debate over the global and the local captured in Castells' (1994) concept of the dual city, which is divided between its cosmopolitan elite and its tribal local communities. Places searching for a brand that distinguishes them from their competitors seize upon the characteristics of the locality, associating themselves with the personalities, events, traditions and relics of the past or the nature of local cultures. Locality is thus both goal and instrument. The dichotomy local/global has a number of apparently inherent corollaries including diversity/uniformity, depth/superficiality, genuineness/speciousness.

However, current place branding prioritises the spectacular elements of local culture assuming a requirement for brevity, selectivity, simplicity and immediacy. This is an assumption based on the perceived goal of branding described critically by Evans (2006:197) as striving "for a distinctive tag and image that can satisfy the footloose tourist, investor and members of the creative class alike". Thus the subtlety and diversity of local cultures is lost, leaving local societies either to adopt the new brands, abandoning the old or to resent and resist the new brand being imposed upon them. Salzburg becomes monopolistically synonymous with Mozart, Liverpool with the Beatles and Nottingham with Robin Hood. Thus places become trapped in single episodes of their long history and particular expressions of their diverse local culture at the expense of all the rest. The stronger and simpler the brand the more likely it is to be successful but also the harder it will be to change in response to changing fashions. There may be more to Konya (Turkey) than 'dancing dervishes', more to Waterloo than a battle and more to New Orleans than traditional jazz but the inclusion of divergent elements in such strong brands would be hazardous and difficult. A variant on such global brands overwhelming the local cultures is where the simplified localism, projected globally, is actually the wrong local culture. This might be termed local epitome branding, where elements from one specific local culture are selected and projected as the epitome of the entire country or region. Scotland, for example, has an internationally recognised national brand in which kilts, bagpipes and the haggis figure prominently. These however were aspects of a specifically highland culture as selected, simplified and then generalised in the course of the nineteenth century 
(see Hobsbawm and Ranger, 1983). This strong globally recognised brand has been successfully imposed on the entire country, including regions and cultures that never contained such elements, at the cost of suppressing other expressions of locality. The Canadian province of Nova Scotia certainly was settled by many migrants from Scotland, many of whom were Highlanders. Equally, however, there were, and are, many other ethnic cultures among the population. The almost complete 'tartanisation' of Nova Scotia as a brand for internal and external consumption was a deliberate policy pursued by governments in the inter-war period (Mackay, 1992) with the result that a single strong and clear province brand overwhelms any alternative (Dembling, 2005).

\section{Towards synergy?}

What is apparent from the above analysis is that culture and place branding are intertwined in a complex relationship characterised by several dilemmas. They need both to promote generic places within global markets and to reinforce a countervailing localism. They need both to express universal values and to differentiate between localities through enhancing the distinctiveness of places. They need both to reflect and celebrate heterogeneity and to enhance cohesion and homogeneity. They also need both to brand economic place products for export, not least through tourism, and to satisfy the objectives of residents. We believe that the synergy between culture and place branding can help with such dilemmas and can be established when three issues are understood:

a) The function of culture as a process that links the place brand with locals;

b) The contribution and effects of the place brand itself to the making of a place's culture;

c) The need to simultaneously support three types of culture within a place (i.e. culture in, culture for and culture of the place).

\section{Culture between place brand and locals}


Culture informs and contributes to place branding not only with its several positive connotations and possible spill-over effects but also by providing a natural connection to the crucial audience of the residents and other insiders who participate in the place's culture. As repeatedly discussed, despite their multiple roles and significance (e.g. Olsson and Berglund, 2009; Braun et al, 2013), local residents are mostly neglected (e.g. Bennett and Savani, 2003; Merrilees et al, 2009). If culture is examined in depth and is evaluated in its full complexity, it might be the strongest link between the place's quintessence and the ways in which this might be expressed through place branding processes (Kavaratzis and Hatch, 2013). The contribution of culture to place branding, however, is minimised if it is over-simplified in order to provide content for superficial promotional activities or meaningless and unsubstantiated identity claims, which in actual effect, disconnect the place brand from local culture. Synergies might be found if the process of culture is appreciated and if place branding attempts what Pratt (2004) terms 'following culture's making'. For Pratt (2004) cultural practices simultaneously take place in the personal realm and society (state, economic and civil), which means that they are simultaneously "public and private, social and economic, and so on. The challenge for anyone seeking to understand the 'production of culture' is not to 'box-off' culture, but to follow its making" (Pratt, 2004: 125). If such an understanding is adopted then place branding can use culture as the basis for the connection between the place brand and its major stakeholders. It is here where the examination of all processes involved in the circuit of culture becomes useful again, offering as it does a way for place branding to follow culture's making thus making place branding more effective as an expression of local identities and locally-rooted aspirations. Culture's contribution to place branding is also minimised when there is no consideration of which and whose cultural elements are being used in which place branding project and for what purpose. Both these problems might be addressed with a re-orientation towards the community or 'the voice of ordinary citizens' (Garcia, 2004) in all stages of place branding projects (i.e. analytical, strategic and participatory as discussed below). 


\section{The place brand as cultural resource}

The relationship between culture and place branding does not stop at the contribution of culture to place branding but includes the reverse. Place brands are cultural phenomena in the sense that they constitute one of the practices that create and circulate meanings. In this sense, place branding also contributes to the place's cultures and this is another reason for greater attention to the pitfalls and dangers that characterise the relationship. There are cases, for example Newfoundland (Ashworth, 2011), where a place brand intended initially for projection to external markets is subsequently adopted by the locals as their identity. All brands are embedded in the meaning systems that people use (Maclaran, 2009) and they create their own cultures while simultaneously drawing from other cultural phenomena. This is beginning to be explored hesitantly in the place branding literature (e.g. Mayes, 2008; Aitken and Campelo, 2011, Kalandides, 2011). Kavaratzis and Hatch (2013) argue that place brands inform the place culture through their facilitation of the identity construction process, part of which concerns the reflection of identity elements back into the place's internal culture. Aitken and Campelo (2011) put culture and the people who create and live it at the core of the place brand. The relationship between brands and culture is described by Maclaran (2009:74) as an "ongoing iteration between contributing to culture and drawing from it". It is, therefore, particularly important to note the suggestion that contemporary brands are offered not as 'cultural blueprints' but as 'cultural resources' for people to use (Holt, 2004). Place brands are valuable if they are offered as ingredients for people to produce their place's culture as they choose. This changes the place branding task into offering stimuli that people will use to form the place's brand on their own and within this process simultaneously discover the essence of the place.

\section{Culture in, for and of the place}

To paraphrase the title of a recent article in this journal (Colomb, 2011b), a possible resolution to the tensions outlined above can be found in the preposition used to connect culture and place: Does 
place branding use and support culture in the place, culture for the place or culture of the place? We have outlined above that it is most commonly culture in the place that is being promoted. Culture in the place refers to the perceived opportunities for cultural consumption as exemplified in the 'event hallmarking' technique. However, this requires a wider strategy and it is the strategic aspect of place branding that assists here. Arguably, culture in the place is an interpretation of culture that is rather disconnected from culture for the place as it does not adequately serve the purpose of fostering cultural development. Culture for the place refers to elements that re-create and circulate meaning within the place's community such as museums and other facilities that foster cultural exchange between people, whether insiders or outsiders. For this to be effectively included in place branding, however, solid knowledge must be evident of what local populations deem important and how this relates to outside audiences. This is only possible with an extended and in-depth analysis of the place and its audiences in the analytical phase of place branding. It is very often argued that one of the main tasks of place branding is to decide on certain brand values (e.g. Kotler et al, 1999; Moilanen and Rainisto, 2008) and the idea is that "the brand values have to be understood and reiterated by citizens" as Julier (2005:872) criticizes. Thus, currently, place branding first articulates values and then attempts to get citizens 'on board'. Instead, the task of responsible place branding might in fact be the opposite: to identify through the analytical part what citizens value and attempt to articulate it.

Culture in the place is also disconnected from the essence of the place, which can be found in culture of the place. Culture of the place refers to cultural features that place-based audiences perceive as belonging to the specific place and linking them together as a community. This brings us again to the issue of 'whose culture' is deemed more important (Zukin, 1995) and 'usable' in branding the place. It is crucial here to examine the governance setting of place branding (Braun, 2012) and the connected issue of the role of stakeholders. It is the participatory aspect of place branding that can assist here. A range of possible synergies can be explored, that without ignoring the need for culture in the place integrate it with culture of and for the place maintaining a careful 
balance between the three. This is only possible if the three aspects of place branding, namely the strategic, the analytical and the participatory are addressed simultaneously by each place branding project.

\section{The end of 'hijacking culture'?}

This article has provided an account of a series of tensions that arise as a result of the current use of culture for place branding purposes and has suggested a set of solutions for these tensions. To conclude, an illustration of the theoretical framework resulting from the above analysis is given in Figure 2, which depicts the complex and reciprocal relationship between culture and place branding.

\section{'INSERT FIGURE 2 AROUND HERE'}

The framework provides a complex but enhanced understanding of the intrinsic links between the two and a more accurate picture than the currently dominant superficial approach illustrated in figure 1. We have argued for three solutions to the problem of 'hijacking culture': a) to use culture as a connecting link between the place brand and locals, b) to treat the place brand as a cultural resource and c) to simultaneously consider culture in, for and of the place. The proposition to refine the interpretations of culture and to get closer to the cultural nature of brands makes place branding a rather internally-focused, collective exercise. As Giovanardi (2011) has also shown a cultural approach to undertaking and analysing place branding projects has significant benefits and, importantly, allows for a greater role of the local community in place branding.

There is clearly a need for further theoretical refinement and justification: this article attempts only to ignite this process. In this effort, important questions that need to be answered revolve around two main themes. This first is an examination of how the above processes occur when people encounter places and place brands. This would focus on better understanding of the 
ways in which place-users actually experience the place's culture and how they create in their minds place brand associations that are based on the place's culture. The second is an overt explication of potential practical measures that help with capturing and initiating the processes involved. This would focus on the ways in which planners and place managers might be able to integrate into their projects the cultural understanding of place brands described above and how they might be able effectively to influence perceptions.

We can conclude with a practical suggestion regarding the second theme that becomes clear. Each and every project attempting to use culture for place branding purposes needs to address simultaneously three prepositions (in, for, of) and three aspects (analytical, strategic and participatory). Each aspect is required to answer central questions regarding each preposition. The answers to these sets of questions can be used for policy purposes in order to plan, prioritise and evaluate projects. Such questions for each stage of projects are presented in Table 1, which integrates questions stemming from the relevance of the circuit of culture and the cultural production chain.

'INSERT TABLE 1 AROUND HERE'

Simultaneously answering those questions and understanding the processes involved might seem a daunting task but it might be an effective way to let culture support local development and to render culture uses beneficial. As long as this is not the case, culture will continue being 'hijacked' to lead to homogenisation instead of distinctiveness; 'hijacked' by urban elites instead of the people who rightfully participate in it; 'hijacked' to ineffectiveness instead of contribution; ultimately, 'hijacked' to lead to disconnection instead of synergy between the branded (the place), the brand co-creators (the internal and external stakeholders) and the brand managers (the public authorities).

Word Count: 8,926 (excluding abstract) 


\section{References}

AITKEN, R. and CAMPELO, A. (2011), 'The four Rs of place branding', Journal of Marketing Management, 27, 913-933.

AL RAOUF, A. (2006), 'Dubaization vs. Glocalization: Territorial Outlook for Arab/Gulf Cities Transformed' (paper presented at the 9th Sharjah Urban Planning Symposium, Sharjah, 2-4 April).

ANHOLT, S. (2007), Competitive identity, the new brand management for countries, regions and cities, Basingstoke, Palgrave McMillan.

ASHWORTH, G.J. (2009), 'The instruments of place branding: how it is done?', European Spatial Research and Policy, 16, 9-22.

ASHWORTH, G.J. (2010), 'Personality association as an instrument of place branding', in G.J. Ashworth and M. Kavaratzis (eds), Towards effective place brand management: Branding European cities and regions, Cheltenham, Edward Elgar, 222-233.

ASHWORTH, G.J. (2011), 'The 'wrong' brands of Newfoundland and their consequences', in J. ten Toonder (ed), Re-exploring Canadian space, Canada Cahiers, Barkhuis Press, 71-83.

ASHWORTH, G.J. and GRAHAM, B.J. (2012), 'European cities: culture and economy', in D. Stone (ed), Oxford Handbook of Post-war European History, Oxford, Oxford University Press.

ASHWORTH, G.J. and KAVARATZIS, M. (2014), 'Cities of culture and culture in cities: The emergent uses of culture in city branding', in T. Haas and Olsson, K. (eds) Emergent Urbanism: Urban Planning \& Design in Times of Systemic and Structural Change, Aldershot, Ashgate, forthcoming.

BENNETT, R. and SAVANI, S. (2003), 'The rebranding of city places: an international comparative investigation', International Public Management Review, 4, 70-87. 
BIANCHINI, F. (1993), 'Culture, conflict and cities: issues and prospects for the '90s', in F. Bianchini and M. Parkinson (eds), Cultural Policy and Urban Regeneration: The West European Experience, Manchester, Manchester University Press, 1-20.

BOLAND, P. (2010), 'Capital of Culture-you must be having a laugh! Challenging the official rhetoric of Liverpool as the 2008 European cultural capital', Social and Cultural Geography, 11, 627645.

BRAUN, E. (2012), 'Putting city branding into practice', Journal of Brand Management, 19, 257-267.

BRAUN, E., KAVARATZIS, M and ZENKER, S. (2013), 'My city - my brand: The role of residents in place branding', Journal of Place Management and Development, 6, 18-28.

BREWIS, J. and JACK, G. (2011), 'Culture: Broadening the critical repertoire', in M. Alvesson, T. Bridgman and H. Willmott (eds), The Oxford handbook of critical management studies, Oxford University Press, 232-250.

BROUDEHOUX, A.M. (2001), 'Image making, city marketing and the aesthetization of social inequality in Rio de Janeiro', in N. Alsayyad (ed) Consuming tradition, manufacturing heritage, London, Routledge, 273-297.

CASTELLS, M. (1994), 'European cities, the informational society and the global economy', New Left Review, March-April, I 204, 18-32.

COLOMB, C. (2011a), Staging the new Berlin: Place marketing and the politics of reinvention post1989, London, Routledge.

COLOMB, C. (2011b), 'Culture in the city, culture for the city? The political construction of the trickledown in cultural regeneration strategies in Roubaix, France', Town Planning Review, 82, 7798.

CRANG, M. (1998), Cultural Geography, London, Routledge.

DEMBLING J. (2005), 'You Play It As You Would Sing It: Cape Breton, Scottishness and the Means of Cultural Production', in RAY, C. (ed) Transatlantic Scots, Tuscaloosa, The University of Alabama Press, 164-186. 
Du GAY, P., HALL, S., JONES, L., MACKAY, H. and NEGUS, K. (1997), Doing Cultural Studies: The history of the Sony Walkman, London, Sage.

ERDOGAN, B. Z. (1999) 'Celebrity endorsement: A literature review', Journal of Marketing Management, 15, 291-314.

EVANS, G. (2001), Cultural Planning: An urban renaissance?, London, Routledge.

EVANS, G. (2006), 'Branding the city of culture: The death of city planning?' in J. Monclus and M. Guardia (eds) Culture, urbanism and planning, Aldershot, Ashgate, 197-213.

FLORIDA, R. (2002), The Rise of the Creative Class and How It's Transforming Work, Leisure, Community and Everyday Life, New York, Basic Books.

GARCIA, B. (2004), 'Cultural policy and urban regeneration in western European cities: lessons from experience, prospects for the future', Local Economy, 19, 312-326.

GARCIA, B. (2005), 'Deconstructing the city of culture: the long-term cultural legacies of Glasgow 1990', Urban Studies, 42, 841-868.

GIBSON, L. and STEVENSON, D. (2004), 'Urban space and the uses of culture', International Journal of Cultural Policy, 10, 1-4.

GIOVANARDI, M. (2011), 'Producing and consuming the painter Raphael's birthplace', Journal of Place Management and Development, 4, 53-66.

GOSPODINI, A. (2009), 'Post-industrial trajectories of Mediterranean European cities: the case of Post-Olympics Athens', Urban Studies, 46, 1157-86.

GOMEZ, M. V. and GONZALEZ, S. (2001) ‘A Reply to Beatriz Plaza's 'The Guggenheim-Bilbao Museum Effect', International Journal of Urban and Regional Research, 25: 898-900.

GOVERS, R. and GO, F. (2009) Place Branding, Basingstoke, Palgrave MacMillan.

GREENBERG, M. (2008), Branding New York: How a City in Crisis was Sold to the World, London, Routledge.

GRODACH, C. (2010), 'Beyond Bilbao: Rethinking Flagship Cultural Development and Planning in Three Californian Cities', Journal of Planning Education and Research, 29, 353-366. 
HANKINSON, G. (2004), 'Relational Network Brands: Towards a Conceptual Model of Place Brands', Journal of Vacation Marketing, 10, 109-121.

HANNA, S. and ROWLEY, J. (2011) 'Towards a Strategic Place Brand-Management Model', Journal of Marketing Management 27, 458-76.

HARVEY, D. (1989) The Condition of Postmodernity, Oxford, Blackwell.

HOBSBAWM, E. and RANGER, T. (eds) (1983), The invention of tradition, Cambridge: Cambridge University Press.

HOLT, D. (2004), How brands become icons: The principles of cultural branding, Boston: Harvard University Press.

JENSEN, O.B. (2007), 'Culture stories: Understanding cultural urban branding', Planning Theory, 6, pp 211-236.

JULIER, G. (2005), 'Urban Designscapes and the Production of Aesthetic Consent', Urban Studies, 42, 869-887.

KALANDIDES, A. (2011), 'The Problem with Spatial Identity: Revisiting the Sense of Place', Journal of Place Management and Development, 4, 28-39.

KAVARATZIS, M. (2004), 'From City Marketing to City Branding', Place Branding and Public Diplomacy, $1,58-73$

KAVARATZIS, M. (2009), 'Cities and Their Brands: Lessons from Corporate Branding', Place Branding and Public Diplomacy 5, 26-37.

KAVARATZIS, M. and ASHWORTH, G.J. (2005), City Branding: An Effective Assertion of Identity or a Transitory Marketing Trick?', Tijdschrift Voor Economische en Sociale Geografie, 96, 506-514. KAVARATZIS, M. and HATCH, M.J. (2013), 'The dynamics of place brands: An identity-based approach to place branding theory', Marketing Theory, 13, 69-86.

KEEL, A. and NATARAAJAN, R. (2012) ‘Celebrity Endorsements and Beyond: New Avenues for Celebrity Branding', Psychology and Marketing, 29, 690-703.

KOTLER, P., ASPLUND, C., REIN, I. and HEIDER, D. (1999), Marketing Places Europe, London, Pearson. 
KUNZMANN, K.R. (2004), 'Culture, Creativity and Spatial Planning', Town Planning Review, 75, 383404.

LUCARELLI, A. and BERG, P.O. (2011). 'City Branding: A State-of-the-Art Review of the Research Domain', Journal of Place Management and Development 4, 9-27.

MAYES, R. (2008), 'A place in the sun: The Politics of Place, Identity and Branding', Place Branding and Public Diplomacy, 4, 124-32.

MACKAY, I. (1992), 'Tartanism Triumphant: The Construction of Scottishness in Nova Scotia 19331954', Acadiensis, XXI, 2, 5-47.

MACLARAN, P. (2009), 'Building Brand Cultures', in E. Parsons and P. Maclaran (eds), Contemporary Issues in Marketing and Consumer Behaviour, Oxford, Elsevier, 73-88.

McEWAN, C. (2005), 'Geography, culture and global change', in P. Daniels, M. Bradshaw, D. Shaw and J. Sidaway (eds), An introduction to human geography: Issues for the $21^{\text {st }}$ century $\left(2^{\text {nd }}\right.$ ed), Harlow, Pearson, 265-282.

MILES, S. and PADDISON, R. (2005), 'Introduction: the rise and rise of culture-led urban regeneration', Urban Studies, 42, 833-839.

MEETHAN, K. (2001) Tourism in Global Society: Place, Culture, Consumption, Basingstoke, Palgrave. MERRILEES, B. , MILLER, D. and HERINGTON, C. (2009), 'Antecedents of residents' city brand attitudes', Journal of Business Research, 62, 362-7.

MOILANEN, T. and RAINISTO, S. (2009), How to Brand Nations, Cities and Destinations: A Planning Book for Place Branding, Basingstoke: Palgrave-McMillan.

MOOR, L. (2011), 'The making of place: Consumers and place-affiliated brands', in A. Pike (ed) Brands and Branding Geographies, Cheltenham, Edward Elgar, 75-90.

OLSSON, K. and BERGLUND, E. (2009), 'City marketing: the role of the citizens', in T. Nyseth and A. Viken (eds) Place Reinvention: Northern Perspectives, Surrey, Ashgate, 127-144.

ORTNER, S. (1973), 'On key symbols', American Anthropologist, 75, 1338-1346. 
PAPPAS, G. (2011), 'Greece deserves better than placemats and paper cups Mr Minister', Huffington Post (www.huffingtonpost.com), 8 December 2011, (accessed 12 January 2012).

PIKE, A. (ed) (2011), Brands and Branding Geographies, Cheltenham: Edward Elgar.

PINE, B.J. and GILMORE, J.H. (1999) The Experience Economy, Boston, MA: Harvard Business School Press.

PLAZA, B. (2000) 'Evaluating the influence of a large cultural artefact in the attraction of tourism: The Guggenheim Museum Bilbao case', Urban Affairs Review, 36, 264-74.

POUTETSI, C. (2011), 'Greece on 7 million placemats in the USA' (in Greek), To Vima (www.tovima.gr), 24 November 2011 (accessed 11 January 2012).

PRATT, A.C. (2004), 'The cultural economy: A call for spatialized 'production of culture' perspectives, International Journal of Cultural Studies, 7, 117-128.

QUINN, B. (2005), 'Arts festivals and the city', Urban Studies, 42, 927-943.

QUINN, B. (2006), 'Problematising 'Festival Tourism': Arts Festivals and Sustainable Development in Ireland', Journal of Sustainable Tourism, 14, 288-306.

RANTISI, N. and LESLIE, D. (2006) 'Branding the Design Metropole: The Case of Montréal, Canada', Area, 38, 364-376.

RICHARDS, G. and WILSON, J. (2004) 'The impact of cultural events on city image: Rotterdam, Cultural Capital of Europe 2001', Urban Studies, 41, 1931-1951.

RODSETH, L. (1998), 'Distributive models of culture: A Sapirian alternative to essentialism', American Anthropologist, 100, 55-69.

SCARAMANGA, M. (2012) 'Talking about art(s): A theoretical framework clarifying the association between culture and place branding', Journal of Place Management and Development, 5, 7080.

SMIRCICH, L. (1983), 'Concepts of culture and organisational analysis', Administrative Science Quarterly, 28, 339-358. 
SWYNDEDOUW, E., MOULAERT, F. and RODRIGUEZ, A. (2002), 'Neoliberal urbanization in Europe: large-scale urban development projects and the new urban policy', Antipode, 34, 542-577. VAN AALST, I. and VAN MELIK, R. (2011), 'City festivals and urban development: Does place matter?', European Urban and Regional Studies, 19, 195-206.

ZENKER, S. and SEIGIS, A. (2012), 'Respect and the city: Resident participation in place marketing', Journal of Place Management and Development, 5, 20-34.

ZENKER, S. and BECKMAN, S.C. (2013a), 'My Place is not Your Place - Different Place Brand Knowledge by Different Target Groups', Journal of Place Management and Development, 6, 6-17.

ZENKER, S. and BECKMANN, S. (2013b) 'Measuring brand image effects of flagship projects for pace brands: The case of Hamburg', Journal of Brand Management, 20, 642-655.

ZUKIN, S. (1995), The cultures of cities, Cambridge, Blackwell.

ZUKIN, S. (2010), Naked city: the death and life of authentic urban places, Oxford, Oxford University Press. 


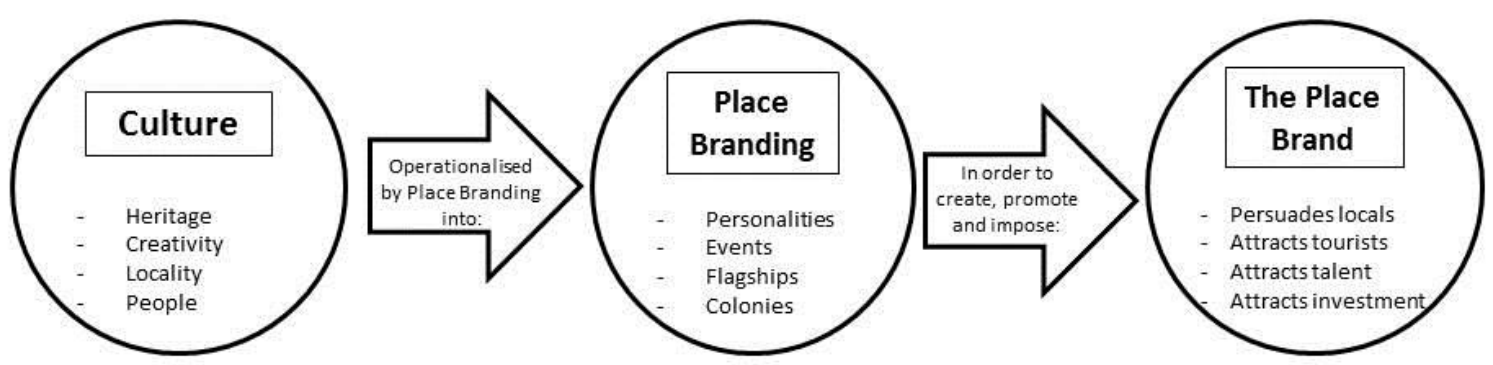

Figure 1: Current superficial relationship between culture and place branding and usage of culture for place branding purposes.

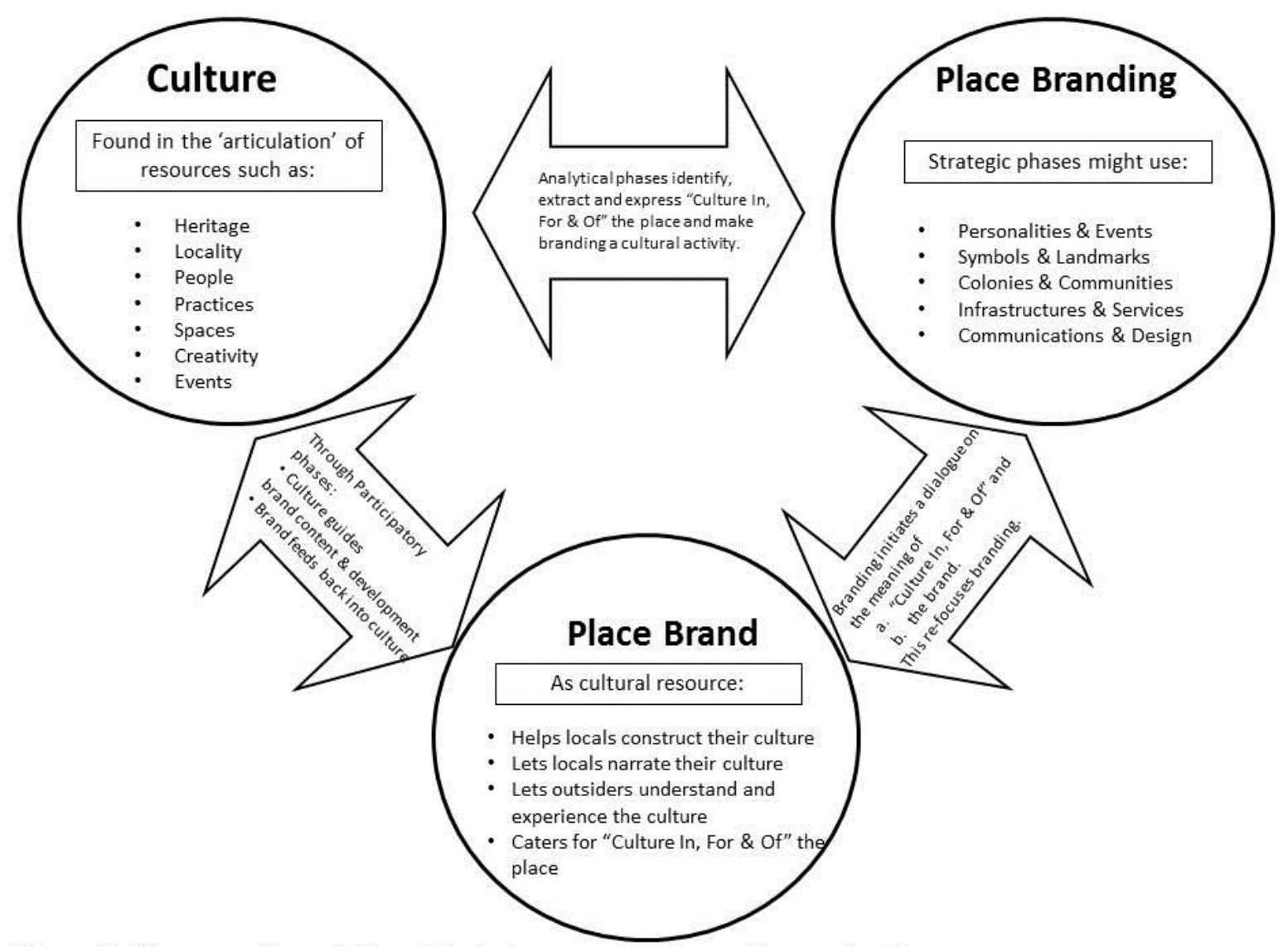

Figure 2: The complex relationship between place branding and culture 


\begin{tabular}{|l|l|}
\hline $\begin{array}{l}\text { Stage of place branding } \\
\text { project }\end{array}$ & Main questions \\
\hline Analytical & $-\begin{array}{l}\text { How can culture of the place be described and how does it relate to and affect cultures in } \\
\text { and for the place? }\end{array}$ \\
\hline What is on offer in terms of culture in and what is its contribution to culture of and for? \\
\hline How does culture for our place currently affect culture of?
\end{tabular}

Table 1: Main questions in relation to culture to be answered by place branding projects 